\title{
Josep Iborra, Fuster, una declinació personal, València, Càtedra Joan Fuster / Publicacions de la Universitat de València, 2014, 290 pp.
}

Pocs escriptors han assistit tan de prop com Josep Iborra a l'evolució personal i literària de Joan Fuster al llarg de la seua vida. Caldria, de fet, remuntar-nos als anys quaranta, en plena postguerra al País Valencià, per copsar amb profunditat l'estreta relació que mantingueren ambdós intel.lectuals durant més de quatre dècades ininterrompudament. Segons recorda Josep Iborra en una entrevista recollida en el llibre col.lectiu Ser Joan Fuster. 33 visions sobre l'escriptor, corria l'any 1949 quan es trobaren per primera vegada en una tertúlia que tenia lloc en un local del carrer de la Pau de València. Fou Fuster qui s'acostà a un joveníssim Iborra, recent arribat d'Alcoi, per a agrair-li la ressenya que havia escrit per a la revista Claustro sobre el seu poemari Ales $o$ mans, que tot just havia eixit a la llum uns mesos abans.

La ressenya esmentada — dissortadament introbable en l'actualitat— es titulava «Un libro de poemas» i constitueix el primer escrit d'Iborra sobre Fuster. Després, en vindrien molts més, com ara l'estudi Fuster portàtil amb què establí les bases de l'exegesi fusteriana i pel qual fou guardonat amb el premi d'assaig Joan Fuster, dels premis Octubre de 1982. No obstant això, caldria esperar fins al 2012 perquè, un any després de la mort d'Iborra, i coincidint amb el cinquantenari de l'edició de Nosaltres, els valencians, Publicacions de la Universitat de València editara Humanisme $i$ nacionalisme en l'obra de Joan Fuster, la tesi doctoral inèdita que refonia i ampliava l'esplèndid Fuster portàtil. Però, quan tot feia pensar que aquest era el seu llibre definitiu sobre l'obra literària de Fuster, encara apareixia el 2014 el volum pòstum Fuster, una declinació personal, una mostra més del seu afany per donar a conéixer l'obra de l'assagista suecà. Es tracta d'un llibre deliberadament miscel-lani que reuneix ressenyes, articles, ponències, parlaments, anotacions de dietari, assaigs i estudis concebuts amb la voluntat d'analitzar, des d'una concepció integral, les diverses formes en què Fuster es presenta al lector a través dels seus escrits.

Fuster, una declinació personal està estructurat en sis nuclis temàtics que presenten l'home i l'escriptor des de l'òptica particular d'Iborra. Tal com ja hem apuntat, el primer capítol — «Coordenades»— serveix per situar el lector davant del corpus fusterià des d'una concepció unitària fonamentada en el racionalisme i el reconeixement de l'originalitat irreductible de l'ésser humà. No debades, és a partir d'aquesta secció, entesa a mode de pòrtic, que el lector ha de dimensionar l'abast dels capítols següents connectant les parcel.les en què es ramifica la vasta, dispersa i fragmentària producció fusteriana.

Partint de les premisses esbossades en el primer capítol, que desfan la vella dicotomia entre l'escriptor escèptic i el personatge cívic, el segon mostra un Fuster, 
si no íntim, sí més personal i exempt d'aures mistificadores. En aquest sentit, el títol «Irreductiblement personal» és del tot escaient per a agrupar els escrits que conformen aquest bloc. Especial atenció mereix la ponència «Joan Fuster, filharmònic», que fou llegida pel professor Iborra en el marc de la VII Jornada Joan Fuster en novembre de 20IO, i que versa sobre les vivències musicals que compartí amb Fuster al llarg de la seua dilatada amistat.

Les seccions tercera i quarta, titulades «Literatura d'idees» $\mathrm{i}$ «La literatura del jo» respectivament, indaguen en la concepció fusteriana de l'assaig i n'estableixen els punts de contacte i de divergència amb autors clàssics com Valéry, Pascal, Montaigne o Rabelais. La varietat de registres formals emprats va des de la ressenya literària fins als apunts i les notes disperses que ens recorden el millor Iborra de Breviari d'un bizantí. No menys remarcable és la ponència «Fuster i Montaigne», pronunciada en novembre de 2005 amb motiu de la celebració de la III Jornada Joan Fuster. Fet i fet, són textos que, si bé no desenvolupen a fons el temes tractats, enlluernen el lector per la seua capacitat analítica i sintètica.

En canvi, el cinqué capítol, designat amb l'epígraf «Text i context», se centra, d'una banda, en les relacions epistolars de Fuster i, de l'altra, en el marc sociopolític i cultural en què va escriure El descrèdit de la realitat. Així, en primer lloc, analitza el periple iniciàtic del jove Fuster que desplega sense treva una intensa i fructífera xarxa epistolar amb els principals escriptors exiliats, i també amb els que van romandre a les Illes, Catalunya i el País Valencià. I, en segon lloc, com a bon coneixedor de les condicions que envoltaven, i condicionaven, la praxi literària de la postguerra, narra amb detall la grisor de la València dels anys quaranta i cinquanta que va conéixer de primera mà, una ciutat culturalment erma on, de manera incomprensible, Fuster fou capaç d'escriure un dels assaigs sobre art més lúcids que mai s'han escrit en la història de la cultura catalana. Tanca el volum el capítol «Joan Fuster i la literatura catalana», que conté tres estudis que sotmeten a examen la relació de l'assaig fusterià amb la tradició catalana moderna i la influència del conjunt de la seua obra sobre les generacions posteriors d'escriptors catalans, amb una atenció particularitzada als assagistes valencians.

Fuster, una declinació personal constitueix el diàleg lúcid i suggeridor de Josep Iborra, no només amb el llegat cultural i literari de Fuster, sinó també amb l'home que, malgrat les incerteses i les adversitats de la seua època, es va fer a ell mateix. En definitiva, un diàleg francament alliçonador de mestre a mestre i d'amic a amic.

Salvador Ortells Miralles

Universitat de València

voro@digitecmedia.com 